\title{
Effectiveness of endovascular thrombolysis in acute mesenteric vein thrombosis
}

\author{
M Milone', G Di Minno², MND Di Minno², V laccarino ${ }^{3}$, P Venetucci $^{3}$, F Milone $^{1 *}$ \\ From XXIII Annual Meeting of the Italian Society of Geriatric Surgery \\ Lecce, Italy. 2-4 December 2010
}

\section{Background}

Mesenteric vein thrombosis (MVT) is a rare, often lethal, entity that accounts for approximately $10-15 \%$ of all cases of mesenteric ischemia [1,2]. Current indications for surgery in patients with acute MVT include signs of peritonitis, bowel infarction and hemodynamic instability.

In all other cases, long-lasting anticoagulation is the strategy of choice $[3,4]$, patients with MVT have a fairly good prognosis and long-term outcomes once appropriate anticoagulation is achieved [4,5]. At variance with the slow onset of recanalization that takes place during anticoagulation, thrombolysis leads to a rapid re-opening of a vessel, with immediate tissue reperfusion [4].

\section{Materials and methods}

We have followed up each for at least 3 years. 32 MVT patients (Table 1), 18 of whom (treated group) had undergone percutaneous transhepatic thrombolysis and mechanical thrombectomy prior to starting long-lasting warfarin treatment. The other 14 patients (control group) received only warfarin treatment. In each case and for each patient, the rate of surgical approach (bowel resection) and the rate of long-term mesentericportal hypertension was evaluated.

\section{Results}

In $16 / 18$ patients $(88.8 \%)$ following the percutaneous treatment, flow restoration in the thrombosed mesenteric vein was documented by direct portal venography (Fig. 1). All patients with successfully recanalized MVT did not develop recurrent episodes during the long-lasting (1 year) oral anticoagulation therapy. The 30-day mortality rate was similar in the two groups $(\mathrm{p}=0.998)$. Bowel resection was needed in 1 patient $(5.5 \%)$ in the treated group and in 5 patients $(35.7 \%)$ in the control group ( $\mathrm{p}=0.022$ as to the rate of short-term surgical sequelae). A significant difference was also found as to

Table 1 Clinical diagnosis on admission

\begin{tabular}{lccc}
\hline & Control Group & Treated group & Statistical significance \\
\hline Asa & 4 & 7 & \\
Asa 2 & 10 & 11 & $\mathrm{P}=0.712$ \\
Asa 3 & 5 & 7 & \\
\hline Thrombosis localization & 7 & 8 & $\mathrm{P}=0.950$ \\
Mesenteric & 2 & 3 & \\
Mesenterico-portal & & & \\
Spleno-mesenter-portal & 1 & 2 & $\mathrm{P}=0.865$ \\
\hline Duration of symptom & 9 & 10 & \\
$\leq 2$ day & 4 & 6 & \\
$\leq 7$ day & & & \\
$\leq 14$ day & & & \\
\hline
\end{tabular}

\footnotetext{
* Correspondence: francesco.milone@unina.it

'Department of Surgery, Orthopedics and Emergency, Unit of General

Surgery, "Federico II" University, Naples, Italy

Full list of author information is available at the end of the article
}

(c) 2011 Milone et al; licensee BioMed Central Ltd. This is an open access article distributed under the terms of the Creative Commons 


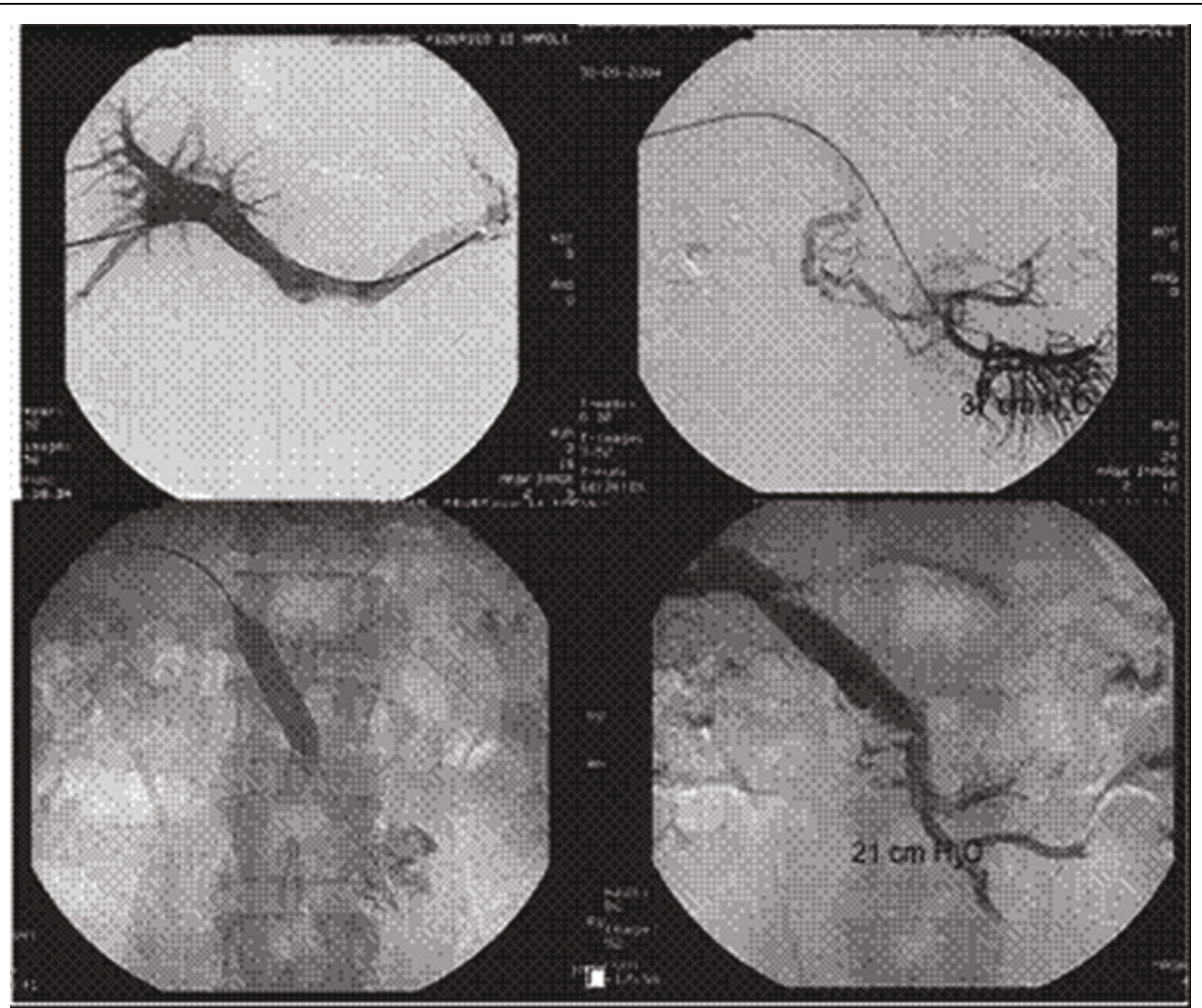

Figure 1 Percutaneous Thrombolysis and venoplasty

long-term sequelae, especially portal hypertension (7/14 patients in the control group, $50.0 \% ; 2 / 18$ patients in the treated group, 11.1\%; $\mathrm{p}=0.043$ ) (Fig. 2).

\section{Conclusions}

MVT is still a serious disease, with a high mortality rate $(25-35 \%)$, mostly related to transmural necrosis and bowel perforation due to the delay in diagnosis $[1,6]$. In the absence of major clinical signs and symptoms, the severity of bowel ischemia on admission is

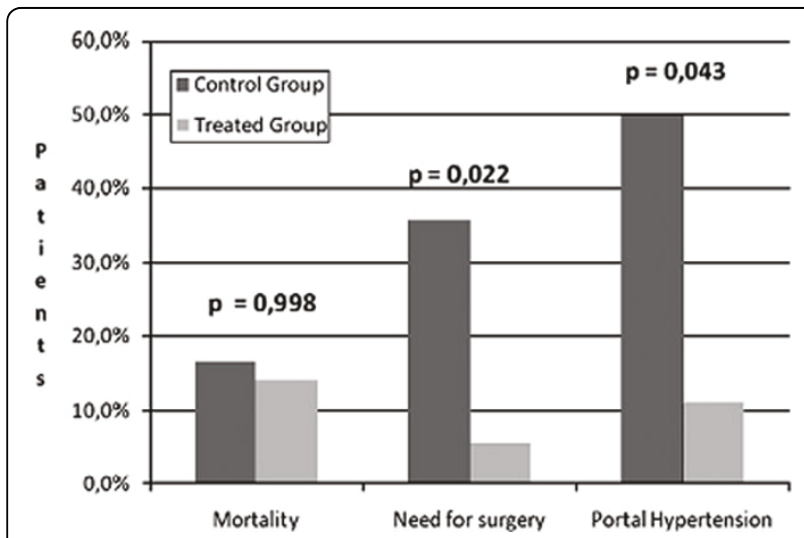

Figure 2 Results of the trial following the pharmacological treatment based on the evaluation of bowel wall thickness by contrast-enhanced CT scan ( $90 \%$ sensitivity). Macroscopically infarcted small bowel without transmural necrosis is potentially reversible with long-lasting anticoagulation [1,7-10]. Encouraging results of endovascular thrombolytic treatments have been reported in literature [11,12]. According to our results, when administered promptly, endovascular intervention using percutaneous transhepatic thrombolysis and mechanical thrombectomy appears to have a lower rate of early and late complications compared to warfarin treatment alone.

\section{Author details}

'Department of Surgery, Orthopedics and Emergency, Unit of General Surgery, "Federico II" University, Naples, Italy. ${ }^{2}$ Department of Clinical and Experimental Medicine, Reference Centre for Coagulation Disorders, "Federico II" University, Naples, Italy. ${ }^{3}$ Department of Radiology and Radiotherapy, Unit of Cardiovascular and Interventional Radiology, "Federico II" University, Naples, Italy.

Published: 24 August 2011

\section{References}

1. McManimon S, Ryu RK, Durham JD: Mesenteric Venous Thrombosis. Tech Vasc Interv Radiol 1998, 1(4):209-15.

2. Divino CM, Park IS, Angel LP, et al: A retrospective study of diagnosis and management of mesenteric vein thrombosis. Am J Surg 2001, 181:20-3.

3. Hefny AF, et al: Management of mesenteric vascular occlusion. Singapore Med J 2008, 49(4):319. 
4. Kitchens CS: Venous thromboses at unusual sites in consultative hemostasis and thrombosis.Alving Kessler, editor. Kitchens. W.B. Saunders Co 2002, 225-42

5. Sreenarasimhaiah Jayaprakash: Diagnosis and management of intestinal ischaemic disorders. BMJ 2003, 326:1372-6.

6. Kumar S, Sarr MG, Kamath PS: Mesenteric venous thrombosis. New Engl Med 2001, 345:1683-8.

7. Morash MD, Ebaugh JL, Chiou AC, Matsumura JS, Pearce WH, Yao JST: Mesenteric venous thrombosis: a changing clinical entity. J Vasc Surg 2001, 34:673-9.

8. Brunaud L, Antunes L, Collinet-Adler S, Marchal F, Ayav A, Bresler L: Acute mesenteric venous thrombosis: Case for nonoperative management. $J$ Vasc Surg 2001, 34(4):673-9.

9. Grieshop RJ, Dalsing MC, Cikrit DF, Lalka SG, Sawchuk AP: Acute mesenteric venous thrombosis. Revisited in a time of diagnostic clarity. Ann Surg 2001, 233:801-7.

10. Barnes Endean ED, SL Kwolek CJ, Minion DJ, Schwarcz TH, Mentzer RM: Surgical management of thrombotic acute intestinal ischemia. Ann Surg 2001, 233:801-7.

11. Hyun S, Kim Md, Ajanta Patra MD, Jaward Khan MD, Aravind Arepally MD, Michael B, et al: Transhepatic Catheter-directed Thrombectomy and Thrombolysis of Acute Superior Mesenteric Venous Thrombosis. J Vasc Interv Radiol 2005, 16:1685-91.

12. Kaplan Jonathan L, Weintraub Sharon L, Hunt John P, Gonzales Arturo, Lopera Jorge, Brazzini Augusto: Treatment of Superior Mesenteric and Portal Vein Thrombosis with Direct Thrombolytic Infusion via an Operatively Placed Mesenteric Catheter. Annual Scientific Meeting and Postgraduate Course Program, Southeastern Surgical Congress Atlanta, GA; 2004.

doi:10.1186/1471-2318-11-S1-A35

Cite this article as: Milone et al:: Effectiveness of endovascular

thrombolysis in acute mesenteric vein thrombosis. BMC Geriatrics 2011

11(Suppl 1):A35.

\section{Submit your next manuscript to BioMed Central and take full advantage of:}

- Convenient online submission

- Thorough peer review

- No space constraints or color figure charges

- Immediate publication on acceptance

- Inclusion in PubMed, CAS, Scopus and Google Scholar

- Research which is freely available for redistribution

Submit your manuscript at www.biomedcentral.com/submit 